\title{
Legitymacja skargowa w postępowaniu sądowoadministracyjnym jako element wpływający na efektywność podejmowania decyzji w administracji publicznej
}

\section{Uwagi wprowadzające}

Jednym z zasadniczych elementów, które stanowią czynnik warunkujący proces podejmowania decyzji przez organy administracji publicznej, jest legitymacja skargowa w postępowaniu sądowoadministracyjnym. Możliwość wyprowadzenia kontroli działań administracji poza pion administracyjny, w obszar postępowania sądowoadministracyjnego, stanowi przejaw prawnych ograniczeń procesów decyzyjnych. Zebranie i zbadanie w jednym opracowaniu dotychczasowych poglądów prezentowanych w doktrynie i orzecznictwie pozwoli na holistyczną ocenę spójności regulacji dotyczących legitymacji skargowej w postępowaniu sądowoadministracyjnym. Ze względu na fakt, iż regulacje te są rozproszone $\mathrm{w}$ wielu aktach normatywnych, ich zbiorcza analiza umożliwi wyciągnięcie wniosków dotyczących stopnia, $\mathrm{w}$ jakim stanowią one prawne ograniczenie procesów decyzyjnych $\mathrm{w}$ administracji. Ponadto analiza prawna problemu będzie narzędziem pomocnym w podjęciu w przyszłości badań natury socjologicznej.

W celu zapewnienia klarownego obrazu zróżnicowanych możliwości zaskarżania działań administracji publicznej w artykule zostanie przedstawiona instytucja legitymacji skargowej o tzw. charakterze uniwersalnym (pkt 1), z zaznaczeniem wykluczeń podmiotowych i analizą znaczenia interesu prawnego, w kontekście identyfikacji podmiotów uprawnionych do zaskarżania. W dalszej kolejności omówieniu podlegać będzie legitymacja podmiotów składających skargę w cudzej sprawie, takich jak prokurator, Rzecznik Praw Obywatelskich, organizacja społeczna, a także - uwzględniając nowelizację z 24 września 2010 r. - Rzecznik Praw Dziecka (pkt 2). Następnie przybliżona zostanie legitymacja do wniesienia skargi na mocy ustaw samorządowych oraz ustawy o wojewodzie i administracji rządowej w województwie (pkt 3) ze szczególnym uwzględnieniem podstawy legitymacji do złożenia skargi przez jednostkę samorządu terytorialnego (JST)

1 Robert Król, przygotowuje rozprawę doktorską z zakresu prawa gospodarczego i handlowego oraz jest założycielem kancelarii KR-RK Legal w Krakowie/Nowym Sączu. 
na rozstrzygnięcie organu nadzoru oraz ograniczeń w zaskarżaniu uchwały, czynności lub braku czynności organu tej jednostki. Na koniec zostaną przedstawione szczególne uprawnienia do zaskarżenia działań administracji, wynikające $\mathrm{z}$ wybranych ustaw stanowiących lex specialis w stosunku do Prawa o postępowaniu przed sądami administracyjnymi (pkt 4).

\section{Legitymacja skargowa o charakterze uniwersalnym}

Już na wstępie zasadne jest postawienie tezy, że legitymacja skargowa de facto przesądza o samej możliwości skontrolowania aktu administracyjnego przez sąd, a więc poza pionem administracyjnym. Postępowanie sądowoadministracyjne ma bowiem charakter kontradyktoryjny - innymi słowy, jest wszczynane wyłącznie w wyniku skargi ${ }^{2}$. Powyższe stwierdzenie prowadzi także do drugiego wniosku - o wyłączeniu samego sądu administracyjnego z kręgu podmiotów uprawnionych do wszczęcia postępowania sądowoadministracyjnego. W ten sposób scharakteryzowano pierwszą z kategorii podmiotów wykluczonych z kręgu uprawnionych do zaskarżania. Drugim rodzajem podmiotów podlegających wykluczeniu są organy, których działanie ma być przedmiotem oceny sądu. Ta kategoria jest rozszerzona o każdy inny organ pozostający w strukturze organizacyjnej tego pionu administracji. Finalną kategorię podmiotów wyłączonych spod zaskarżania danego aktu bądź czynności tworzą podmioty wykonujące zadania zlecone przez organ, który wydał owo rozstrzygnięcie ${ }^{3}$. Wnioskując a contrario z powyższych ustaleń, uprawnienie do uruchomienia postępowania sądowoadministracyjnego $\mathrm{w}$ formie legitymacji skargowej ma dopiero podmiot, którego cechuje odrębność od całości struktury hierarchicznie oraz funkcyjnie powiązanych ze sobą organów administracji ${ }^{4}$.

Dokonawszy podstawowych wykluczeń natury podmiotowej można przedstawić podstawy legitymacji skargowej pierwszej z kategorii podmiotów uprawnionych do zaskarżania działań (bądź bezczynności) organów administracji. Na początku trzeba ustalić, jaki czynnik jest faktycznie

$2 \mathrm{Na}$ marginesie należy wskazać wyjątek od powołanej reguły, przejawiający się w sytuacji wszczęcia postępowania w sprawie odtworzenia akt w przypadku ich zaginięcia lub zniszczenia (art. $289 \$ 1$ ustawy z dnia 30 sierpnia 2002 r. - Prawo o postępowaniu przed sądami administracyjnymi, Dz. U. z 2016 r. poz. 718 ze zm.; dalej p.p.s.a.). Jest to jednak postępowanie określane jako pomocnicze i trudno dopatrywać się w nim spornego charakteru. W takim postępowaniu nie dochodzi bowiem do naruszenia niczyjego interesu, a tym samym do sporu z organem administracji. Jest to z praktycznego punktu widzenia forma czynności technicznej. Jedynie istotność materiału, jakiego ona dotyczy (odtworzenie akt stanowiących istotny element postępowań spornych), oraz to, iż jest ona wykonywana przez sąd, nadaje tej czynności rangę postępowania.

3 Taki krąg wykluczeń podmiotowych był wielokrotnie postulowany w doktrynie (w szczególności zob. T. Woś, H. Knysiak-Molczyk, M. Romańska, Prawo o postępowaniu przed sądami administracyjnymi. Komentarz, T. Woś (red.), Kraków 2009).

4 Ibidem, s. 273. 
podstawą dla legitymacji skargowej uniwersalnej. Zgodnie z treścią art. 50 $\$ 1$ p.p.s.a.: „Uprawnionym do wniesienia skargi jest każdy, kto ma w tym interes prawny" ". Zaznaczenia wymaga, iż interes prawny w postępowaniu sądowoadministracyjnym nie jest tożsamy $\mathrm{z}$ interesem prawnym zawartym w art. 28 ustawy z dnia 14 czerwca 1960 r. - Kodeks postępowania administracyjnego ${ }^{6}$ jest to nowa kategoria interesu wyróżniona przez Prawo o postępowaniu przed sądami administracyjnymi, odmienna od interesu prawnego w postępowaniu administracyjnym ${ }^{7}$, która posiada szerszy zakres $^{8} \mathrm{w}$ tym sensie, iż można dociekać jego istnienia $\mathrm{z}$ obszerniejszego wachlarzu źródeł ${ }^{9}$. W tym miejscu niezbędne jest podkreślenie, iż struktura interesu prawnego w postępowaniu sądowoadmnistracyjnym nakazuje

5 Sformułowanie zawarte $\mathrm{w}$ art. $50 \$ 1$ p.p.s.a. stwarza pewne wątpliwości w wykładni unormowań tej ustawy, jeżeli analizując szerzej, połączy się je z normą opisującą wymogi formalne skargi jako pisma procesowego kwalifikowanego. Zgodnie z ową regulacją: „skarga (...) powinna ponadto zawierać: (...) określenie naruszenia prawa lub interesu prawnego" (art. $57 \$ 1$ pkt 3 p.p.s.a.). Przytoczony fragment art. 57 $\$ 1$ pkt 3 p.p.s.a. może sugerować, iż legitymację należałoby oprzeć nie tyle na konieczności określenia naruszenia obiektywnego porządku prawnego, co raczej na obowiązku wykazania naruszenia interesu prawnego skarżącego przez akt, czynność bądź też bezczynność organu. Jednak badanie przez sąd już na etapie składania skargi, czy faktycznie wykazane przez skarżącego naruszenie indywidualnego interesu prawnego ma miejsce, byłoby błędne (zob. A. Duda, Interes prawny w polskim prawie administracyjnym, Warszawa 2008, s. 218). Sytuacja taka byłaby sprzeczna z intencją ustawodawcy, według którego podstawowym celem nadzoru sprawowanego przez sądy administracyjne jest zapewnienie legalności działalności administracji publicznej. Sąd administracyjny jako priorytet traktuje stwierdzenie, a następnie wyeliminowanie istnienia naruszenia prawa przez organ administracji.

6 Tekst jedn.: Dz. U. z 2016 r. poz. 23 ze zm.; dalej k.p.a.

7 Zob. wyrok NSA z dnia 17 marca 2015 r., II OSK 1955/13, LEX nr 1665729, zgodnie z którym „o istnieniu legitymacji procesowej strony w postępowaniu sądowoadministracyjnym nie decyduje zarzut naruszenia interesu prawnego skarżącego, lecz interes prawny, którego istotę stanowi żądanie oceny przez właściwy sąd administracyjny zgodności zaskarżonego aktu lub czynności z obiektywnym stanem prawnym”. Stanowisko to przeważa także w poglądach doktrynalnych, zob. T. Woś [w:] T. Woś (red.), Postępowanie sądowoadministracyjne, T. Woś (red.), Warszawa 2015, s. 118; J. Zimmermann, Polskie sądownictwo administracyjne (uwagi o projekcie ustawy o Naczelnym Sądzie Administracyjnym), „Krakowskie Studia Prawnicze” 1993-1994, s. 40-41 i 45; odmienne stanowisko zajął W. Chróścielewski, Legitymacja skargowa w postępowaniu sądowoadministracyjnym, „Zeszyty Naukowe Sądownictwa Administracyjnego" 2010, nr 5-6, s. 81-82.

8 K. Chorąży, W. Taras, A. Wróbel, Postępowanie administracyjne egzekucyjne i sądowoadministracyjne, Kraków 2009, s. 304.

9 Potwierdzenie tezy o istnieniu nowej kategorii interesu prawnego można znaleźć m.in. w: J. Zimmermann, Glosa do postanowienia NSA z dnia 19 sierpnia 2004 r., OZ 340/04, „Orzecznictwo Sądów Polskich” 2005, z. 4, s. 21. Autor ten stwierdza także, w: J. Zimmermann, Prawo administracyjne, Warszawa 2008, s. 380, iż prawo do wniesienia skargi jest odrębnym publicznym prawem podmiotowym i stanowi element prawa do sądu i sprawiedliwego procesu, J. Zimmermann, Prawo administracyjne, Warszawa 2008, s. 380. 
rozróżnienie dwóch aspektów: obiektywnego, przez który należy rozumieć interes we wniesieniu skargi (tj. interes prawny w przeprowadzeniu sądowej kontroli prawnej), oraz subiektywnego, przejawiającego się w interesie w doprowadzeniu zaskarżonego aktu do stanu zgodnego z obiektywnym porządkiem prawnym ${ }^{10}$.

\subsection{Obiektywny aspekt legitymacji uniwersalnej}

W przypadku aspektu obiektywnego analizujemy występowanie interesu prawnego podmiotu skarżącego w skontrolowaniu zgodności aktu bądź czynności z ogólnym porządkiem prawnym. Oznacza to, iż skarżący musi wykazać w skardze niezgodność zaskarżonego aktu z obiektywnie obowiązującymi normami prawa. Są to więc normy, które obowiązują niezależnie od indywidualnych interesów podmiotów występujących w postępowaniu administracyjnym.

Takie rozumienie legitymacji skargowej jest zgodne $\mathrm{z}$ intencją ustawodawcy. Zgodnie z jego wolą legitymacja skargowa ma bowiem służyć jako jeden $\mathrm{z}$ elementów ochrony obiektywnego porządku prawnego. Legitymacja do wniesienia skargi z natury swej konstrukcji umożliwia ochronę obiektywnego porządku prawnego poprzez prawo do inicjacji postępowania sądowego, jednak samo jej wniesienie nie przesądzi o zasadności takiej skargi. Nie można utożsamiać legitymacji skargowej ze złożonym zbiorem zależnych od siebie elementów, które dopiero występując wspólnie, zapewniają ochronę obiektywnego porządku prawnego. Niemniej jednak uznanie legitymacji skargowej za jedno z narzędzi ochrony obiektywnego porządku prawnego znajduje swoje uzasadnienie w systemie regulacji postępowania przed sądami administracyjnymi.

Wniosek taki można wysnuć, wychodząc poza obszar regulacji, którą obejmuje art. 50 p.p.s.a. i spoglądając całościowo na unormowania z dziedziny sądownictwa administracyjnego. Pierwszy czynnik potwierdzający powyższą hipotezę można odnaleźć w akcie regulującym ustrój sądów administracyjnych, czyli w ustawie z dnia 25 lipca 2002 r. - Prawo o ustroju sądów administracyjnych ${ }^{11}$. Artykuł $1 \$ 2$ w zw. z $\$ 1$ p.u.s.a., stanowiący normę wyznaczającą zakres, treść i charakter uprawnień kontrolnych sądów administracyjnych, wskazuje, iż sąd sprawuje kontrolę zaskarżonych aktów i czynności „pod względem ich zgodności z prawem”. Taki zapis nie pozostawia wątpliwości co do głównego zadania wyznaczonego sądom, a w konsekwencji co do roli, jaką ma spełniać uprawnienie do zaskarżania przez dany podmiot, od którego wymaga się wykazania interesu prawnego w skontrolowaniu legalności aktu. Drugim zestawem norm stanowiących potwierdzenie tezy o ochronie obiektywnego porządku prawnego jako nad-

10 Zob. wyrok WSA we Wrocławiu z dnia 23 marca 2011 r., IV SA/Wr 715/10, LEX nr 950603.

11 Tekst jedn.: Dz. U. z 2016 r. poz. 1066 ze zm. 
rzędnego celu legitymacji skargowej, są unormowania regulujące zakres i zasady orzekania przez sąd (art. 145-150 p.p.s.a.). Jednoznacznie ukazują one właściwy kierunek rozumienia legitymacji skargowej w postępowaniu sądowoadministracyjnym ${ }^{12}$. Regulacja ta, ustalająca, w jakich przypadkach sąd uwzględnia skargę już na etapie orzekania (innymi słowy, na etapie oceny merytorycznej, po wniesieniu skargi), wskazuje jako przesłanki różne rodzaje naruszeń wspomnianego wyżej porządku prawnego. Ponadto obiektywne rozumienie interesu prawnego jest także powoływane w orzecznictwie. Wojewódzki Sąd Administracyjny w Warszawie w postanowieniu z dnia 8 czerwca 2006 r., II SA/Wa 355/06 stwierdza, iz „w przypadku aspektu obiektywnego [legitymacji procesowej skarżącego - przyp. R.K.] należy wziąć pod uwagę fakt wystosowania przez dany podmiot żądania przeprowadzenia kontroli określonego aktu administracyjnego pod kątem jego zgodności z prawem"13. Tak jednoznaczna intencja ustawodawcy co do roli sądowej kontroli administracji wydaje się dobitnie potwierdzać słuszność interpretacji interesu prawnego skarżącego jako interesu w skontrolowaniu zgodności z prawem aktu lub czynności organu. Skoro celem nadzoru sprawowanego przez sądy administracyjne jest zapewnienie legalności działalności administracji publicznej, to badanie naruszenia indywidualnego interesu prawnego $\mathrm{w}$ połączeniu $\mathrm{z}$ koniecznością wniesienia skargi dla uruchomienia postępowania skutecznie ograniczałoby taką kontrolę $^{14}$. Przyjmując założenie kontroli legalności jako priorytetowej funkcji sądu administracyjnego, należy dopuścić sytuację, w której skarżący jedynie zaznaczy w skardze istnienie naruszenia swojego interesu prawne-

12 Więcej w przedmiocie obiektywnego porządku prawnego jako nadrzędnego celu legitymacji skargowej zob. w T. Woś, H. Knysiak-Molczyk, M. Romańska Postępowanie..., s. 98.

13 LEX nr 221869.

14 Dla weryfikacji tej tezy należy rozważyć założenie alternatywne - przyjęcie literalnej wykładni przepisów art. $50 \$ 1$ p.p.s.a. w zestawieniu z przepisem traktującym o wymogach formalnych skargi, tj. art. 57 p.p.s.a. Zgodnie z art. $50 \$ 1$ „uprawnionym do wniesienia skargi jest każdy, kto ma w tym interes prawny" Analizując normę opisującą wymogi formalne skargi jako pisma procesowego kwalifikowanego, należy zwrócić uwagę, iż zgodnie $\mathrm{z}$ art. $57 \$ 1$ pkt 3 p.p.s.a. „skarga (...) powinna ponadto zawierać: (...) określenie naruszenia prawa lub interesu prawnego" - taki zapis wydaje się sugerować, że skarżący musi wykazać naruszenie jego interesu prawnego, a nie tylko obiektywnego porządku prawnego. W praktyce oznaczałoby to badanie przez sąd już na etapie składania skargi, czy faktycznie wykazane przez skarżącego naruszenie indywidualnego interesu prawnego ma miejsce. Taka sytuacja mijałaby się z intencją ustawodawcy, według którego podstawowym celem nadzoru sprawowanego przez sądy administracyjne jest zapewnienie legalności działalności administracji publicznej (badanie naruszenia indywidualnego interesu prawnego w połączeniu z koniecznością wniesienia skargi dla uruchomienia postępowania skutecznie ograniczałoby taką kontrolę). 
$\mathrm{go}^{15}$, bez konieczności jego udowadniania, już na etapie składania skargi ${ }^{16}$. $\mathrm{W}$ praktyce jednak należy spodziewać się, że podmiot będzie składał skargę, wyrażając swoje niezadowolenie z zaskarżanego aktu, a więc reprezentując swoje prywatne interesy, a tylko formalnie powoła się na naruszenie przez akt, czynność bądź jej brak prawa procesowego lub materialnego ${ }^{17}$. Takie działanie zostanie podjęte $\mathrm{w}$ celu uniknięcia, po uprzednim wezwaniu przez organ do uzupełnienia braków, odrzucenia skargi z przyczyn formalnych na podstawie art. 57 p.p.s.a. ${ }^{18}$ Warto zaznaczyć, że na taką postawę skarżącego nie będzie mógł oddziaływać w żadnym stopniu organ, którego akt zostaje zaskarżany. Organ, przed którym toczyło się postępowanie i za pośrednictwem którego wnoszona jest skarga, nie ma żadnego bezpośredniego wpływu na legitymację skargową strony postępowania. Nie ma prawa oceniać jej zasadności czy też celowości, a także jej procesowej legalności. Nawet w przypadku uchybienia terminowi do wniesienia skargi organ nie ma prawa orzekania o konsekwencji takiego uchybienia. W sytuacji procesowych uchybień może jedynie za pomocą odpowiedzi na skargę wnosić o jej odrzucenie, powołując się na zaistniałą okoliczność ${ }^{19}$.

\subsection{Subiektywny aspekt legitymacji uniwersalnej}

Drugą stroną legitymacji skargowej podmiotu indywidualnego jest płaszczyzna subiektywna. Pomimo podniesionych uprzednio uwag legitymacja o charakterze uniwersalnym nadal dotyczy możliwości złożenia skargi we własnej sprawie. Na podstawie $\$ 1$ art. 50 p.p.s.a. nie można składać skargi od aktu, z którym skarżący nie ma żadnego związkư ${ }^{20}$. Skarga

15 Zob. m.in. T. Lewandowski, Glosa do wyroku WSA $z$ dnia 2 kwietnia 2012 r., I SAB/Wa 67/12, LEX nr 386030691, gdzie autor wskazuje, iż prawodawca nie wymaga przedstawienia $\mathrm{w}$ treści skargi kompleksowego i wyczerpującego wywodu prawnego wskazującego na konkretne normy prawne, które zostały naruszone określonym zaniechaniem organu.

16 W literaturze dotyczącej tematyki legitymacji skargowej można spotkać określenie powyższej sytuacji jako „domniemania” istnienia sprawy sądowoadministracyjnej. Tłumaczy się to tym, iż de facto wynik kontroli legalności działania organu administracji przesądza o zasadności skargi. W dalszej konsekwencji oddalenie skargi przez sąd na podstawie braku naruszenia interesu prawnego skarżącego nie dotyczy zasadności skargi, a jedynie jej procesowej legalności (zob. A. Duda, Interes prawny..., s. 228-229).

17 W. Chróścielewski, Wszczęcie postępowania sądowoadministracyjnego, „Państwo i Prawo” 2004, z. 3, s. 69.

18 Innymi słowy, inicjatywa wszczęcia postępowania sądowoadministracyjnego de facto jest uzależniona od decyzji jednostki. Może więc ona złożyć skargę na działanie organu, bazując na swoim przekonaniu, iż zaskarżane rozstrzygnięcie było dla niej krzywdzące (zob. J. Zimmermann, Polskie sadownictwo administracyjne..., s. 38-39).

19 Szerzej w tym przedmiocie W. Chróścielewski, Wszczęcie postępowania..., s. 71.

20 Zob. T. Woś, H. Knysiak-Molczyk, M. Romańska, Prawo o postępowaniu..., s. 274. 
indywidualnego podmiotu powinna więc dotyczyć aktu lub czynności, która jest związana $z$ jego własnymi prawami bądź obowiązkami ${ }^{21}$. Wojewódzki sąd administracyjny w Warszawie, opierając się na powyższej tezie, stwierdza w postanowieniu z dnia 8 czerwca $2006 \mathrm{r}$. „W sensie subiektywnym, stroną [postępowania sądowoadministracyjnego - przyp. R.K.] jest strona stosunku materialnoprawnego, który był przedmiotem konkretyzacji w postępowaniu administracyjnym"22. Także Naczelny Sąd Administracyjny wyraźnie opowiada się za wymogiem wykazania związku pomiędzy skarżącym a sprawą administracyjną. W swym wyroku z dnia 3 czerwca 1996 r., II SA 74/96 ${ }^{23}$ stwierdza, że konieczne jest, w przypadku wnoszenia skargi, działanie we własnym imieniu i posiadanie roszczenia o przyznanie uprawnienia lub zwolnienia $\mathrm{z}$ nałożonego obowiązku. $\mathrm{W}$ tym miejscu, w pewnym stopniu wywodząc myśl z wyżej przywołanego stanowiska NSA, należy wskazać, iż nie jest konieczne, by podmiot legitymowany do złożenia skargi był stroną postępowania administracyjnego ${ }^{24}$. Wystarczy, że w pewien sposób, nawet błędny, konkretyzacja stosunku materialnoprawnego dotknęła praw lub obowiązków tego podmiotu (będzie tak przykładowo w przypadku, w którym wydano decyzję wobec nieprawidłowego podmiotu). Tym samym błędne (a więc niemające oparcia w przepisach prawa administracyjnego materialnego) uznanie podmiotu za stronę poprzez skierowanie do niego aktu lub wykonanie wobec niego danej czynności wyposaża taki podmiot w legitymację do złożenia skargi ${ }^{25}$. Posiada on bo-

21 Zob. M. Mrówczyński, Legitymacja skargowa w postępowaniu sądowoadministracyjnym wynikająca $z$ ustaw szczególnych, „Zeszyty Naukowe Sądownictwa Administracyjnego" 2015, nr 6, s. 19.

22 Postanowienie WSA w Warszawie z dnia 8 czerwca 2006 r., II SA/Wa 355/06.

23 Wyrok NSA z dnia 3 czerwca 1996 r., II SA 74/96, „Orzecznictwo Naczelnego Sądu Administracyjnego" 1997, nr 2, poz. 89.

24 Odmiennie: wyrok NSA z dnia 27 września 2000 r., II SA 2109/00, LEX nr 47586, w którym sąd wskazał, iż samo błędne skierowanie decyzji do osoby niebędącej stroną postępowania administracyjnego, a co więcej, niemającej żadnego interesu prawnego w rozstrzygnięciu sprawy i której to rozstrzygnięcie w ogóle nie dotyczy - nie może uzasadniać jej interesu prawnego do wniesienia skargi do NSA (art. 33 ust. 2 nieobowiązującej już ustawy o NSA). Na marginesie należy zaznaczyć, że treść art. 33 ust. 2 ustawy o NSA jest niemal tożsama $z$ treścią art. $50 \$ 1$ p.p.s.a. co powoduje, iż przytoczone orzeczenie pozostaje aktualne w powołanej kwestii. Zob. glosę krytyczną J. Borkowskiego, „Orzecznictwo Sądów Polskich” 2001, z. 6. Legitymacja skargowa podmiotu niebędącego stroną postępowania administracyjnego jest dopuszczana także w najnowszym orzecznictwie: zob. wyrok NSA z dnia 27 lutego 2014 r., II OSK 2343/12, LEX nr 1495268 oraz wyrok NSA z dnia 17 marca 2015 r., II OSK 1955/13.

25 Powyższą myśl potwierdza zdiagnozowanie konieczności zaistnienia powiązania pomiędzy skarżącym a zaskarżonym aktem bądź działaniem jako ogólnego ograniczenia kontroli sądowej (zob. J. Zimmermann, Polskie sądownictwo administracyjne..., s. 40). Tym samym szersze rozumienie tego ograniczenia (tj. obowiązek bycia stroną w postępowaniu administracyjnym) stałoby w sprzeczności z zasadą legalności poprzez niedopuszczenie do skontrolowania aktu potencjalnie niezgodnego z obowiązującym porządkiem prawnym wskutek skargi podmiotu, do którego taki akt został skierowany. 
wiem interes prawny w doprowadzeniu zaskarżonego aktu do stanu zgodnego z prawem, co nie jest koniecznie tożsame $\mathrm{z}$ interesem w postępowaniu administracyjnym ${ }^{26}$. Interes prawny może więc być wywodzony również $\mathrm{z}$ prawa procesowego ${ }^{27}$ i ustrojowego, nie tylko $\mathrm{z}$ materialnego, jak ma to miejsce $\mathrm{w}$ postępowaniu administracyjnym ${ }^{28}$. Część doktryny prezentuje także stanowisko odmienne, zgodnie z którym interes prawny istnieje wyłącznie w przypadku gdy jest możliwe wskazanie przepisu prawa materialnego, z którego wywodzi się dla danego podmiotu prawa i obowiązki ${ }^{29}$. Sytuacja podmiotu, do którego zostało skierowane rozstrzygnięcie organu administracyjnego, a który nie jest stroną w sprawie administracyjnej, jest traktowana jako wyjątek od tej reguły. W takim przypadku nadal jednak mamy do czynienia $\mathrm{z}$ wywodzeniem interesu $\mathrm{z}$ prawa procesowego ${ }^{30}$. Inte-

26 Zob. J. Zimmermann, Glosa do wyroku NSA z dnia 2 lutego 1996 r., sygn. akt IV SA 846/95, „Orzecznictwo Sądów Polskich” 1997, z. 4, poz. 83 oraz W. Chróścielewski, Glosa do wyroku WSA w Warszawie $z$ dnia 27 stycznia 2004 r., III SA 1617/02, „Orzecznictwo Sądów Polskich” 2005, z. 11, poz. 128. Takie stanowisko przyjmuje także współczesne orzecznictwo, por. m.in. wyrok WSA we Wrocławiu z dnia 23 marca 2011 r., IV SA/Wr 715/10.

27 Zob. m.in. wyrok SN z dnia 26 maja 2006 r., III RN 170/99, „Orzecznictwo Sądu Najwyższego. Izba Administracyjna, Pracy i Ubezpieczeń Społecznych” 2001, nr 5, poz. 140.

28 Sprecyzowania wymaga także kategoria przepisów prawa, które mogą chronić interes prawny $\mathrm{w}$ postępowaniu administracyjnym, ten sam interes, $\mathrm{z}$ którym - jak wykazano w niniejszym artykule - podmiot musi wykazać związek, składając skargę. Błędne byłoby stwierdzenie, iż dopuszczalna jest tylko dziedzina prawa administracyjnego. NSA wskazuje, iż istotą takiego interesu prawnego jest jego związek z normą prawną i że w tym przypadku dopuszczalna jest norma należąca do każdej dziedziny prawa, na podstawie której określony podmiot, w danym stanie faktycznym, może domagać się konkretyzacji jego uprawnień lub obowiązków bądź żądać kontroli określonego aktu lub czynności w celu ochrony jego praw lub obowiązków (tak wyrok NSA z dnia 24 listopada 2004 r., OSK 919/04, „Orzecznictwo Sądów Polskich” 2005, z. 11, poz. 128).

29 Takie stanowisko jest prezentowane przez J. Tarnę (Prawo o postępowaniu przed sq̨dami administracyjnymi. Komentarz, Warszawa 2009, s. 151), według którego w opisanej sytuacji interesu prawnego podmiotu w postępowaniu sądowoadministracyjnym należy upatrywać $\mathrm{w}$ prawie do wyeliminowania $\mathrm{z}$ obrotu prawnego decyzji adresowanej do osoby niebędącej stroną (art. $156 \$ 1$ pkt 4 k.p.a.).

30 Dlatego też ustalenie braku istnienia interesu prawnego, który wywodziłby się z norm prawa administracyjnego, powinno powodować, iż sąd wyeliminuje akt bądź czynność organu administracji, która została bezprawnie podjęta, nie zaś, że oddali skargę ze względu na brak możliwości legitymowania się przez podmiot tym interesem prawnym, zob. T. Woś, H. Knysiak-Molczyk, M. Romańska Prawo o postępowaniu..., s. 275. Jeszcze w stosunku do starej ustawy o NSA, ale o niezmienionej w tym zakresie regulacji, Naczelny Sąd Administracyjny pierwszy raz ustalił wyrokiem z dnia 27 maja 1988 r., IV SA 164/88, iż niedopuszczalna jest sytuacja odrzucenia skargi podmiotu, który nie był stroną w postępowaniu administracyjnym. Odrzucenie bądź oddalenie takiej skargi skutkowałoby pozbawieniem podmiotu prawa do sądu i zgodą sądu na pozostawienie w obrocie prawnym aktu jasno łamiącego przepisy prawa materialnego. 
res w skontrolowaniu danego aktu bądź czynności w opisanej sytuacji wynika bowiem $z$ samego procesowego faktu wydania rozstrzygnięcia organu administracji, które zostało zaadresowane do podmiotu skarżącego. W tym miejscu należy przypomnieć, że sąd nie powinien badać faktycznego istnienia interesu prawnego występującego w postępowaniu administracyjnym. $\mathrm{W}$ przeciwnym przypadku, gdyby sąd mógł badać jego istnienie, a co za tym idzie mieć możliwość odrzucenia skargi, podmiot niebędący stroną w postępowaniu administracyjnym byłby pozbawiony środków odwoławczych od postanowienia sądu o odrzuceniu skargi ${ }^{31}$.

\section{Podmioty składające skargę w cudzej sprawie}

Drugą kategorią podmiotów, które zostały objęte regulacją art. $50 \leqq 1$ p.p.s.a., są podmioty, które posiadają szczególne uprawnienia w postępowaniu sądowoadministracyjnym. Prokurator, Rzecznik Praw Obywatelskich, Rzecznik Praw Dziecka i organizacja społeczna mogą składać skargę w sprawie dotyczącej interesów innych osób, jeżeli zakres naruszenia będzie pokrywał się z obszarem kompetencji wyżej wspomnianych podmiotów i instytucji ${ }^{32}$. Legitymacja ta przysługuje im na podstawie procesowych i ustrojowych uprawnień, a nie - jak miało to miejsce w przypadku pierwszej kategorii skarżących $\mathrm{z}$ art. 50 p.p.s.a. - w oparciu o ich związek $\mathrm{z}$ prawem materialnym. Wyjątek do pewnego stopnia stanowi przypadek organizacji społecznej. Podstawą legitymacji prokuratora i Rzecznika Praw Obywatelskich jest wyłącznie ochrona obiektywnego porządku prawnego ${ }^{33}$, podczas gdy od organizacji społecznej wymaga się spełnienia dodatkowych warunków. Należy zauważyć, iż legitymacja wszystkich trzech kategorii podmiotów wnoszących skargę w cudzej sprawie opiera się na samym elemencie formalnym legitymacji podmiotów indywidualnych, tj. na żądaniu kontroli sądowej legalności danego aktu bądź czynności ${ }^{34}$. Poniżej zostaną omówione wybrane zagadnienia szczególnie istotne z perspektywy praktycznej.

\subsection{Prokurator}

W stosunku do legitymacji prokuratora interesujące zagadnienie porusza NSA w swym wyroku z dnia 4 maja 2004 r., OSK 55/045. Prokuratorowi, zgodnie z tezą wyroku NSA, przysługuje prawo wniesienia skargi bez

31 W. Chróścielewski, Strony i uczestnicy postępowania administracyjnego, „Państwo i Prawo" 2004, z. 9, s. 37-38.

32 T. Woś, H. Knysiak-Molczyk, M. Romańska, Prawo o postępowaniu..., s. 289.

33 B. Dauter, B. Gruszczyński, A. Kabat, M. Niezgódka-Medek, Prawo o postępowaniu przed sądami administracyjnymi. Komentarz, Warszawa 2009, s. 163-164.

34 A. Duda, Interes prawny..., s. 229-230.

35 „Wokanda” 2004, nr 7-8, poz. 56. 
wymogu wprowadzonego przez art. 52 p.p.s.a. - tj. obowiązku uprzedniego wykorzystania wszystkich środków odwoławczych w postępowaniu administracyjnym. Zwolnienie to nie obejmuje jednak sytuacji, w której prokurator brał udział w postępowaniu administracyjnym na prawach strony. W takim przypadku obowiązuje go wykorzystanie środków odwoławczych tak jak każdą inną stronę. Należy zauważyć, iż decyzja o wszczęciu postępowania sądowoadministracyjnego bądź udziału w nim leży wyłącznie w ręku prokuratora i sąd administracyjny nie ma prawa oceniać jej słuszności. Artykuł $52 \$ 1$ p.p.s.a. zezwala więc na rozróżnienie sytuacji procesowej prokuratora w zależności od tego, czy brał on udział w postępowaniu administracyjnym czy nie ${ }^{36}$. Nie ma bowiem podstaw prawnych dla stworzenia korzystniejszej sytuacji procesowej prokuratorowi występującemu w postępowaniu administracyjnym na prawach strony od strony takiego postępowania. Taka wykładnia opierałaby się na dosłownym brzmieniu art. 52 p.p.s.a., pomijając jednocześnie jego wykładnię systemową ${ }^{37}$ i celowościo$\mathrm{wą}^{38}$.Zastosowanie wykładni celowościowej w opisanej sytuacji jest dodatkowo uzasadnione przy przyjęciu poglądu, zgodnie z którym weryfikacja aktu na drodze administracyjnej ma pierwszeństwo przed weryfikacją w trybie postępowania sądowoadministracyjnego ${ }^{39}$.

\subsection{Rzecznik Praw Obywatelskich}

Zgodnie z art. 14 pkt 6 ustawy z dnia 15 lipca 1987 r. o Rzeczniku Praw Obywatelskich $^{40}$, może on wnieść skargę do sądu administracyjnego na prawach przysługujących prokuratorowi. Występują jednak pewne istotne różnice podyktowane odmiennymi od prokuratorskich ustawowymi celami i zadaniami RPO. Uprawnienie do zaskarżania przez Rzecznika jest, podobnie jak legitymacja występująca w skardze uniwersalnej, powiązane z ochroną interesu prawnego. Różnica polega na tym, iż nie jest to interes własny Rzecznika, a interes podmiotu indywidualnego, którego prawa i wolności zostały naruszone rozstrzygnięciem organu administracji. Legitymacja RPO, zarówno w postępowaniu administracyjnym, jak i sądowoadministracyjnym, opiera się bowiem na przesłance naruszenia praw i wolności, a w konsekwencji na konieczności usunięcia dostrzeżonego

36 Zob. uchwałę składu 7 sędziów NSA w Warszawie z dnia 10 kwietnia 2006 r., I OPS 6/05, LEX nr 182498 odnoszącą się do art. 34 ust. 1 ustawy o NSA (obecnie art. 52 $\$ 1$ p.p.s.a.).

$37 \mathrm{~W}$ przedmiocie sprzeczności systemowej, jaka wystąpiłaby w przypadku stosowania literalnej wykładni regulacji art. 52 p.p.s.a. zob. P. Brzozowski, Glosa do uchwały NSA $z$ dnia 10 kwietnia 2006 r., I OPS 6/05, LEX nr 385958940.

38 Zob. wyrok NSA z dnia 4 maja 2004 r., OSK 55/04.

39 B. Adamiak [w:] B. Adamiak, J. Borkowski, Postępowanie administracyjne i sądowoadministracyjne, Warszawa 2005, s. 428-429.

40 Tekst jedn.: Dz. U. z 2017 r. poz. 958 ze zm. 
przez Rzecznika naruszenia ${ }^{41}$. Legitymacja skargowa RPO nie jest ograniczona wyłącznie do osób fizycznych i to posiadających obywatelstwo polskie. Artykuł 208 ust. 1 Konstytucji, zgodnie z którym „Rzecznik Praw Obywatelskich stoi na straży wolności i praw człowieka i obywatela określonych w Konstytucji oraz w innych aktach normatywnych"42, literalnie rozumiany mógłby sugerować takie ograniczenie. Należy jednak zwrócić się w stronę szerokiego pojmowania zakresu kompetencji Rzecznika, za którym opowiedział się Sąd Najwyższy. W swym wyroku stwierdza on, $\mathrm{iż}, \mathrm{W}$ sensie podmiotowym działalność Rzecznika Praw Obywatelskich obejmuje te podmioty prawne, które mogą korzystać z konstytucyjnie zagwarantowanych wolności i praw podstawowych"43. W takim rozumieniu kompetencje RPO obejmowały, prócz obywateli, wszystkie osoby fizyczne, a także korporacje prawa prywatnego, które można podzielić na trzy grupy. Z jednej strony mamy organizacje osób fizycznych - inaczej korporacje osobowe - takie jak związki zawodowe, stowarzyszenia, partie polityczne, a także inne organizacje będące realizacją kolektywnych praw i wolności, przez które należy rozumieć m.in. konstytucyjne prawo wolności zrzeszania $\operatorname{się}^{44}$. Drugą kategorią są korporacje o charakterze majątkowym takie jak spółki prawa handlowego. Do trzeciej grupy należą inne osoby prawne. Zaliczyć do nich można m.in. takie korporacje prawa publicznego jak samorząd zawodowy (przykładowo samorząd adwokacki, lekarzy czy też architektów). Ochrona RPO w stosunku do wyżej wymienionych podmiotów zależy od celu, w jakim zostały one utworzone i zakresu ich działalności. Wniesienie przez Rzecznika skargi na rozstrzygnięcie krzywdzące dla korporacji publicznoprawnej będzie możliwe jedynie w takim zakresie, $\mathrm{w}$ jakim przysługują jej zagwarantowane przez Konstytucję wolności i prawa obywatela $^{45}$. Rzecznik Praw Obywatelskich, podobnie jak prokurator, jest zwolniony z obowiązku wyczerpania wszystkich środków odwoławczych przed wniesieniem skargi. Także podobnie jak w sytuacji prokuratora przywilej ten nie przysługuje w przypadku gdy Rzecznik brał udział w postępowaniu administracyjnym jako strona. Wyłącznie od autonomicznej woli RPO zależy decyzja o wszczęciu postępowania sądowoadministracyjnego bądź udziału w nim.

Kończąc zestawienie wybranych cech szczególnych legitymacji Rzecznika, trzeba wskazać jeszcze jedno ograniczenie - strona postępowania administracyjnego jest obowiązana wykorzystać środki odwoławcze, by Rzecz-

41 S. Trociuk, Ustawa o Rzeczniku Praw Obywatelskich. Komentarz, Łódź 2005, s. 72 .

42 Konstytucja Rzeczypospolitej Polskiej z dnia 2 kwietnia 1997 r., Dz. U. Nr 78, poz. 483 ze zm., art. 208 ust. 1.

43 Wyrok z dnia 5 kwietnia 2002 r., III RN 133/01, „Orzecznictwo Sądu Najwyższego Izba Pracy, Ubezpieczeń Społecznych i Spraw Publicznych” 2002, nr 12, poz. 281.

44 Art. 58 Konstytucji RP.

45 T. Woś, H. Knysiak-Molczyk, M. Romańska Prawo o postępowaniu..., s. 290. 
nik mógł złożyć skargę w jej imieniu. W przeciwnym przypadku podmiot indywidualny, chcąc uniknąć konieczności wykorzystania środków odwoławczych przed wniesieniem skargi, mógłby zwrócić się z wnioskiem o złożenie jej przez Rzecznika. W takiej sytuacji RPO powinien odmówić, jednocześnie wskazując wnioskodawcy przysługujące mu środki odwoławcze, z których podmiot ten może skorzystać. W konsekwencji składanie skargi przez RPO odbywa się na zasadzie subsydiarności ${ }^{46}$. Na podobnych przesłankach oparta jest legitymacja skargowa Rzecznika Praw Dziecka w postępowaniu sądowoadministracyjnym. Rzecznik Praw Dziecka przy wykonywaniu swoich uprawnień kieruje się dobrem dziecka oraz bierze pod uwagę, że naturalnym środowiskiem jego rozwoju jest rodzina. Zgodnie $\mathrm{z}$ dodanym nowelą do Prawa o postępowaniu przed sądami administracyjnymi z 2010 r. $\$ 2$ w art. 8 p.p.s.a. Rzecznik Praw Dziecka może wnieść skargę do sądu administracyjnego. Regulacja ta ma umożliwić realizację art. 1 ust. 2 i 3 ustawy z dnia 6 stycznia 2000 r. o Rzeczniku Praw ${ }^{47}$, zgodnie z którymi Rzecznik Praw Dziecka stoi na straży praw dziecka określonych w Konstytucji Rzeczypospolitej Polskiej, Konwencji o prawach dziecka przyjętej przez Zgromadzenie Ogólne Narodów Zjednoczonych dnia 20 listopada 1989 r. $^{48} \mathrm{i}$ innych przepisach prawa, z poszanowaniem odpowiedzialności, praw i obowiązków rodziców ${ }^{49}$.

\subsection{Organizacja społeczna}

Podstawą wniesienia skargi przez organizację społeczną jest, jak sama nazwa tej instytucji wskazuje, ochrona interesu społecznego. W kwestii legitymacji skargowej organizacji społecznej można dostrzec istotne ograniczenia w jej uprawnieniach do wniesienia skargi. Przyczyną jest sformułowanie zawarte $w$ art. $50 \$ 1$ p.p.s.a., zgodnie z którym organizacja społeczna uprawniona jest do wniesienia skargi „w zakresie jej statutowej działalności, w sprawach dotyczących interesów prawnych innych osób, jeżeli brała udział w postępowaniu administracyjnym" [wyróżnienie R.K.]. Skutkiem powyższej regulacji jest powstanie czterech rodzajów ograniczeń legitymacji skargowej przysługującej organizacji społecznej. Do pierwszej kategorii należą ograniczenie zawężające zakres udziału organizacji tylko do postępowań uregulowanych w Kodeksie postępowania administracyjnego, w których wydawane są decyzje i postanowienia. Zawężenie to jest

46 Zob. w szczególności S. Trociuk, Ustawa o Rzeczniku Praw Obywatelskich..., s. 41 i 79.

47 Tekst jedn.: Dz. U. z 2017 r. poz. 922 ze zm.

48 Dz. U. z 1991 r. Nr 120, poz. 526 z późn. zm.

49 Zob. także T. Woś, H. Knysiak-Sudyka, M. Romańska, Prawo o postępowaniu przed sadami administracyjnymi. Komentarz, T. Woś (red.), Warszawa 2016; H. Knysiak-Sudyka, Skarga i skarga kasacyjna w postępowaniu sądowoadministracyjnym. Komentarz i orzecznictwo, Warszawa 2016. 
podyktowane wymogiem udziału organizacji społecznej w postępowaniu administracyjnym, a więc postępowaniu regulowanym przepisami Kodeksu. Kodeks postępowania administracyjnego ogranicza zaskarżalność aktów wydawanych w regulowanych przez siebie postępowaniach do decyzji i postanowień. Należy przy tym zaznaczyć, iż nie wszystkie rodzaje decyzji i postanowień mogą być zaskarżone przez organizacje społeczną. Istnieje możliwość, iż w ustawie szczególnej nie zostanie przewidziany udział organizacji społecznej w rodzaju postępowania administracyjnego, które taka ustawa reguluje. Jest to drugi rodzaj ograniczeń legitymacji skargowej organizacji społecznej. Taka sytuacja występuje w praktyce w ustawie z dnia 7 lipca 1994 r. - Prawo budowlane, która reguluje m.in. sprawy pozwoleń na budowę ${ }^{50}$. Trzeci typ ograniczeń stwarza fakt, iż na podstawie art. $31 \S 1$ k.p.a. żądanie wszczęcia lub dopuszczenia organizacji społecznej do udziału w postępowaniu administracyjnym musi być uzasadnione celami statutowymi tej organizacji oraz musi za nim przemawiać interes społeczny lub, w przypadku postępowania podatkowego, interes publicz$n y^{51}$. Czwartym typem ograniczenia legitymacji skargowej organizacji społecznej jest ograniczenie wynikające z konieczności zaistnienia już samego faktu udziału organizacji społecznej w postępowaniu administracyjnym. Zbieżność tego rodzaju ograniczenia $\mathrm{z}$ wymogiem formalnej dopuszczalności udziału organizacji w danym postępowaniu jest pozorna, gdyż omawiany przypadek dotyczy sytuacji organizacji, która posiada już podstawy prawne i statutowe do udziału w danym postępowaniu administracyjnym, a od legitymacji skargowej oddziela ją jedynie problem, czy faktycznie brała w nim udział. To, czy organizacja wystąpi w charakterze podmiotu na prawach strony w postępowaniu administracyjnym, zależy od dwóch czynników. Po pierwsze, czy w ogóle wykazała inicjatywę w postaci zgłoszenia żądania dopuszczenia do udziału w postępowaniu. Drugim czynnikiem jest dopuszczenie organizacji do udziału w postępowaniu przez organ, który prowadzi takie postępowanie. W zależności od przyjęcia jednego z prezentowanych w doktrynie poglądów drugi z powołanych czynników (dopuszczenie organizacji do udziału w postępowaniu) może mieć decydujące znaczenie. Przy przyjęciu założenia, że także i w opisywanym przypadku sąd nie ma prawa oceniać działań organów administracji w zakresie przysługujących im uprawnień uznaniowych, dopuszczenie organizacji do postępowania administracyjnego decyduje de facto o możliwości wniesienia skargi. Teza ta zakłada, iż ocena organu w przedmiocie dopuszczenia organizacji społecznej do postępowania administracyjnego jest wiążąca dla sądu ${ }^{52}$. Od-

50 Tekst jedn.: Dz. U. z 2016 r. poz. 290 ze zm., art. 28 ust. 3.

51 Tym samym organizacja społeczna, która nie może powołać się w danej sytuacji na interes społeczny lub której zakres działalności statutowej nie obejmuje danej sprawy, nie będzie miała możliwości wszczęcia postępowania w tej sprawie.

52 Tak m.in. T. Woś, H. Knysiak-Molczyk, M. Romańska Prawo o postępowaniu..., s. $291 \mathrm{i} \mathrm{n.}$ 
mienne stanowisko zakłada, iż sąd powinien badać słuszność oceny organu administracji ze względu na jej zakres. W ocenie zwolenników tego stanowiska zależność wszczęcia lub udziału organizacji społecznej w postępowaniu administracyjnym od przesłanki zgodności materii postępowania z celami statutowymi tej organizacji powoduje, iż sąd, któremu przysługuje prawo do badania tej przesłanki w postępowaniu sądowoadministracyjnym, będzie mógł je rozszerzyć na postępowanie administracyjne ${ }^{53}$.

\section{Legitymacja w ustawach samorządowych i w ustawie o wojewodzie i administracji rządowej w województwie jako lex specialis w stosunku do Prawa o postępowaniu przed sądami administracyjnymi}

\subsection{Skarga powszechna}

Zgodnie $\mathrm{z}$ art. $50 \$ 2$ p.p.s.a.: „Uprawnionym do wniesienia skargi jest również inny podmiot, któremu ustawy szczególne przyznają prawo do wniesienia skargi". Najbardziej rozpowszechniony rodzaj legitymacji przyznanej na podstawie powyższej delegacji, potocznie nazywany skargą powszechną, został wprowadzony przez regulację ustaw samorządowych i ustawy o administracji rządowej. Warto zwrócić uwagę, iż w konsekwencji regulacji art. $50 \$ 2$ p.p.s.a. zostają utrzymane $w$ mocy: ustawa $\mathrm{z}$ dnia 8 marca 1990 r. o samorządzie gminnym ${ }^{54}$, ustawa z dnia 5 czerwca 1998 r. o samorządzie powiatowym ${ }^{55}$, ustawa $\mathrm{z}$ dnia 5 czerwca 1998 r. o samorządzie województwa ${ }^{56}$ oraz ustawa z dnia 23 stycznia 2009 r. o wojewodzie i administracji rządowej w województwie ${ }^{57}$. Warto zwrócić uwagę, iż ustawy samorządowe obowiązywały na długo przed wejściem w życie Prawa o postępowaniu przed sądami administracyjnymi. Następstwem takiej konstrukcji systemu regulującego legitymacje w postępowaniu sądowoadministracyjnym jest zaistnienie istotnych różnic pomiędzy legitymacją skargową indywidualną a skargą na akty prawa miejscowego i inne akty podejmowane przez jednostki samorządu terytorialnego z zakresu administracji publicznej oraz na akty nadzoru nad działalnością tych jednostek. Istotne różnice występują także pomiędzy samymi ustawami stanowiącymi lex specialis w stosunku do Prawa o postępowaniu przed sądami administracyjnymi. Zgodnie z treścią art. 101 ust. 1 u.s.g. oraz art. 86 u.s.p. pod-

53 Zob. J. Tarno, Prawo o postępowaniu..., s. 156. Autor uzasadnia opisaną tezę, powołując się na tożsamość pojęcia zgodności celu organizacji z zakresem sprawy w obu postępowaniach (administracyjnym i sądowoadministracyjnym).

54 Tekst jedn.: Dz. U. z 2016 r. poz. 446 ze zm., dalej u.s.g.

55 Tekst jedn.: Dz. U. z 2016 r. poz. 814 ze zm., dalej u.s.p.

56 Tekst jedn.: Dz. U. z 2016 r. poz. 186 ze zm., dalej u.s.w.

57 Tekst jedn.: Dz. U. z 2015 r. poz. 525 ze zm. 
stawą wniesienia skargi jest naruszenie interesu prawnego uchwałą podjętą przez organ jednostki samorządu terytorialnego. Ustawa o samorządzie gminnym, prócz uchwały, wymienia także zarządzenie jako akt mogący naruszać interes prawny. Natomiast art. 90 ust. 1 u.s.w. uznaje już konkretnie, że wyżej wspomniane naruszenie może nastąpić w wyniku wydania aktu prawa miejscowego odpowiednio przez organ samorządu województwa oraz wojewodę lub organ administracji niezespolonej. Ograniczenie $\mathrm{z}$ ustawy o samorządzie województwa powoduje, iż te normy prawne regulują wnoszenie skargi jedynie od aktów prawa miejscowego ustanowionych przez organy tych jednostek administracji - takie zawężenie możliwości zaskarżania jest jednak pozorne, bowiem aktem normatywnym, który należy do zakresu prawa miejscowego, jest właściwie każdy abstrakcyjny i generalny akt wydany przez ustawowo upoważniony organ ${ }^{58}$. Należy podkreślić, iż przesłanką legitymującą do złożenia skargi powszechnej jest naruszenie interesu prawnego, a nie samo jego występowanie ${ }^{59}$. Ten element legitymacji jest mocno akcentowany w orzecznictwie, gdzie szczególny nacisk kładzie się na aktualność nie tylko samego interesu prawnego w chwili wnoszenia skargi, ale przede wszystkim na aktualność jego naruszenia ${ }^{60}$, a także jego bezpośredniość ${ }^{1}$. W dalszej konsekwencji zdolność naruszenia interesu prawnego podmiotu danym aktem wydanym przez jednostkę samorządu terytorialnego jest w orzecznictwie klasyfikowana jako jeden z elementów uprawniających do zaskarżania tego aktu ${ }^{62}$. Choć akty podlegające zaskarżeniu należy rozpatrywać w kontekście lokalnego obszaru ich oddziaływania, to samą legitymację do ich zaskarżania powinno traktować się w spo-

58 Oznacza to, że każdy akt odnoszący się do danej kategorii podmiotów, a więc nie do indywidualnie oznaczonej osoby, oraz przeznaczony do wykorzystywania w nieograniczonej liczbie przypadków w przyszłości, wydany przez uprawniony do tego organ województwa, będzie aktem prawa miejscowego (zob. J. Lemańska, Koncepcja samorządu województwa na tle porównawczym, Kraków 2006, s. 126). Stąd też regulacje wszystkich ustaw samorządowych w praktyce będą dotyczyć legitymacji skargowej na te same kategorie aktów.

59 Zob. wyrok NSA z dnia 18 września 2003 r., II SA 2637/02, LexisNexis nr 363387; wyrok NSA z dnia 25 maja 2006 r., II OSK 1422/05, LexisNexis nr 2589316; wyrok WSA w Lublinie z dnia 14 grudnia 2010 r., II SA/Lu 444/10, LexisNexis nr 2622302; wyrok WSA w Poznaniu z dnia 27 czerwca 2012 r., IV SA/Po 237/12, LexisNexis nr 5798344.

60 Zob. wyrok NSA z dnia 22 lipca 2008 r., I OSK 277/08, LEX nr 490092, w którym sąd wskazuje, iż naruszenie interesu konkretnej osoby ma polegać na stworzeniu realnego zagrożenia, istniejącego już w chwili wejścia w życie uchwały, a jeżeli nie zostanie zniwelowane na skutek wezwania do usunięcia naruszenia prawa, w dacie wniesienia skargi do sądu administracyjnego. Naruszenie to nie może polegać na tym, że w przyszłości uchwała mogłaby wywołać skutki bliżej nieokreślone, czyli stwarzać zagrożenie wystąpienia naruszenia.

61 Zob. wyrok WSA w Lublinie z dnia 14 grudnia 2010 r., II SA/Lu 444/10.

62 Zob. wyrok NSA z dnia 22 grudnia 2010 r., II OSK 1203/10, LexisNexis nr 2484164 . 
sób oderwany od miejscowego aspektu, a przy uwzględnieniu wpływu aktu na interes prawny podmiotów, których akt dotyczy. Określenie aktów, od których przysługuje skarga na podstawie ustaw samorządowych i ustawy o wojewodzie i administracji rządowej w województwie, jako aktów cechujących się przymiotem miejscowym czy też lokalnym, może sugerować, iż podobnie należałoby rozumieć pojęcie interesu prawnego, którego naruszenie jest podstawą legitymacji skargowej w tych ustawach. Niemniej jednak legitymacja skargowa będzie przysługiwać podmiotom niebędącym mieszkańcami danej jednostki samorządu terytorialnego bądź nawet niebędących osobami fizycznymi. Pozbawienie legitymacji skargowej wszystkich osób poza mieszkańcami danej jednostki ze względu na założenie, że akt generalny JST nie może dotyczyć podmiotu niebędącego jej mieszkańcem, byłoby błędne. Dla zobrazowania takiej nieprawidłowości należy posłużyć się przykładem. Załóżmy hipotetyczną sytuację, w której gmina, na podstawie swych kompetencji wynikających $\mathrm{z}$ ustawy o podatkach i opłatach lokalnych ${ }^{63}$, podejmuje uchwałę ustalającą stawki podatku od nieruchomości znajdujących się na terytorium tej gminy ${ }^{64}$. Osoba niebędąca mieszkańcem, a więc członkiem wspólnoty, a jednocześnie posiadająca nieruchomości na terenie tej gminy, przy przyjęciu tezy o objęciu legitymacją skargową wyłącznie mieszkańców danej jednostki byłaby pozbawiona ochrony prawnej.

Do kategorii aktów, w stosunku do których będzie przysługiwała legitymacja do złożenia skargi powszechnej, można zaliczyć: uchwały ustalające stawki podatku od nieruchomości, uchwały statutowe określające ustrój jednostki samorządu terytorialnego, uchwały regulujące zasady sytuowania na obszarze gminy miejsc sprzedaży alkoholów, uchwały uznające drzewa za pomniki przyrody, uchwały wprowadzające zakaz ruchu pojazdów mechanicznych na danym obszarze miasta, a w przypadku wojewody lub wójta także każde zarządzenie porządkowe.

Legitymacja do złożenia tzw. skargi powszechnej jest oparta na zaistnieniu naruszenia interesu prawnego lub uprawnienia - rozróżnienie to (wyartykułowane $\mathrm{w}$ przepisach ustaw samorządowych, a także $\mathrm{w}$ ustawie o wojewodzie i administracji rządowej w województwie) nie wydaje się być słuszne - nie spełnia wymogów alternatywy zwykłej. Pojęcie takie jak „uprawnienie” de facto mieści się w zakresie pojęcia interesu prawnego skarżącego ${ }^{65}$, niemniej jednak należy zauważyć, iż wśród poglądów dok-

63 Ustawa z dnia 12 stycznia 1991 r. o podatkach i opłatach lokalnych, tekst jedn.: Dz. U. z 2016 r. poz. 716 ze zm.

64 Przykład zaczerpnięty z opracowania A. Dudy, Interes prawny..., s. 244.

65 Zob. T. Woś, Glosa do wyroku z 26 VI 1992, III ARN 31/92, „Państwo i Prawo” 1995, z. 2, s. 112. Przyglądając się definicjom pojęć „interes prawny” i „uprawnienie”, powinniśmy dostrzec ich wspólny zakres. Interes prawny to inaczej związek między sferą indywidualnych praw i obowiązków podmiotu skarżącego wynikających z norm prawa materialnego lub procesowego a zaskarżonym aktem. Uprawnienie zaś to przyznana podmiotowi możliwość działania. Dystynkcja pomiędzy tymi dwoma pojęcia- 
trynalnych można odnaleźć także odmienną ocenę wzajemnych zależności pomiędzy interesem prawnym a uprawnieniem ${ }^{66}$. Sprawa, $w$ której będzie wydany zaskarżany akt, może być nazwana „sprawą publiczną" w kontraście do sprawy indywidualnej znanej z $\$ 1$ art. 50 p.p.s.a. Oznacza to, że sprawa będzie mogła dotyczyć przykładowo całej społeczności mieszkańców danej jednostki samorządu terytorialnego, a nie kilku tylko podmiotów - może być więc wywodzona ze znacznie bardziej różnorodnych norm prawnych. Należy przez to rozumieć przepisy prawa materialnego, ustrojowego, normy określające zadania i kompetencje samorządu terytorialnego oraz przepisy organizacyjne. W konsekwencji także interes prawny będzie wywodzony z wszystkich wyżej wymienionych rodzajów regulacji. Tym samym skarżący będzie mógł powołać się na naruszenia praw lub obowiązków wynikających także ze sfery praw grupowych ${ }^{67}$, niemniej jednak i wtedy będzie wskazywał na naruszenie swojego interesu prawnego oraz interesów indywidualnych pozostałych podmiotów, w imieniu których występuje ${ }^{68}$, a nie powoływał się na powody takie jak troska o dobro społeczności lokalnej. Tezę tę popierają rozliczne wyroki sądowe, w uzasadnieniach przekreślając możliwość zaskarżania przy powoływaniu się na interes mieszkańców ${ }^{69}$, zagrożenie dla demokracji lokalnej ${ }^{70}$ czy też interes publiczny $^{71}$. Obecnie

mi jest pozorna i niepotrzebnie wyróżniona przez przepisy samorządowe (podobnie P. Chmielnicki, K. Bandarzewski, P. Dobosz, W. Kisiel, P. Kryczko, M. Mączyński, S. Płażek, Komentarz do ustawy o samorządzie gminnym, Warszawa 2007, s. 580-581). Wyraźnie można zauważyć, iż uprawnienie jest niejako częścią wydobytą z zakresu pojęcia interesu prawnego.

$66 \mathrm{~W}$ tej kwestii należy przywołać tezę K. Bandarzewskiego, zgodnie z którą przez „uprawnienie” można rozumieć prawo podmiotowe. Wówczas następuje rozszerzenie definicji tego terminu $\mathrm{w}$ stosunku do interesu prawnego. Uprawnienie bowiem może odnosić się bowiem do sytuacji, w której podmiot, będąc zainteresowany wydaniem rozstrzygnięcia, ma roszczenie o wydanie rozstrzygnięcia o określonej treści, jeżeli występują przesłanki jego wydania (K. Bandarzewski, M. Chlipała, P. Chmielnicki, P. Dąbek, W. Kisiel, M. Mączyński, S. Płażek, Komentarz do ustawy o administracji rządowej w województwie, Warszawa 2007, s. 328-329). Jednak właściwie rozumiany interes prawny w ocenie autora niniejszego artykułu obejmuje także takie żądanie, gdyż jest to po prostu interes prawny w wydaniu rozstrzygnięcia o danej treści.

67 T. Woś, Glosa do wyroku z 26 VI 1992, III ARN 31/92.., s. 113.

68 J. Zimmermann, Konstrukcja interesu prawnego w sferze działań Naczelnego Sadu Administracyjnego [w:] Gospodarka, administracja, samorząd. Księga dedykowana Profesor Teresie Rabskiej, „Prace Wydziału Prawa i Administracji Uniwersytetu im. Adama Mickiewicza w Poznaniu", t. II, H. Olszewski, B. Popowska (red.), Poznań 1997, s. 617.

69 Wyrok NSA z dnia 11 maja 2006 r., II OSK 145/06, LEX nr 236471.

70 Wyrok NSA z dnia 1 lipca 1999 r., II SA/Ka 2458/98, „Wokanda” 2000, nr 3, s. 37.

71 Wyrok NSA w Warszawie z dnia 13 grudnia 1999 r., IV SA 872/99, LEX nr 48223, a także wyrok SN z dnia 7 marca 2003 r., III RN 42/02, LexisNexis nr 366020, „Orzecznictwo Sądu Najwyższego Izba Pracy, Ubezpieczeń Społecznych i Spraw Publicznych" 2004, nr 7, poz. 114; wyrok WSA w Krakowie z dnia 14 czerwca 2012 r., II SA/Kr 1648/11, LexisNexis nr 5147665. 
zagadnienie legitymacji do zaskarżania aktów prawa miejscowego wydanych w sprawie z zakresu administracji publicznej w województwie reguluje ustawa z dnia 23 stycznia 2009 r. o wojewodzie i administracji rządowej w województwie ${ }^{72}$. Przedmiot zaskarżenia $\mathrm{z}$ tytułu legitymacji przyznanej przez art. 63 tej ustawy wprost wskazuje treść samej regulacji, jest to akt prawa miejscowego wydany w sprawie z zakresu administracji publicznej ${ }^{73}$. Legitymacja procesowa występująca w oparciu o ustawę o wojewodzie i administracji rządowej w województwie posiada pokrewny charakter do legitymacji z ustaw samorządowych. Tak jak w ustawach samorządowych $\mathrm{w}$ art. 63 komentowanej ustawy zawarto wymóg legitymowania się naruszeniem interesu prawnego dla skutecznego wniesienia skargi. W konsekwencji napotykamy te same wątpliwości interpretacyjne prowadzące do tej samej konkluzji, iż chodzi o subiektywne, ale uzasadnione przekonanie skarżącego, że dane ustalenie narusza jego prawa ${ }^{74}$. Z powodów przytoczonych już przy omawianiu ustaw samorządowych należy dojść do wniosku, iż legitymacja skargowa przysługuje niezależnie od miejsca zamieszkania. Na poparcie tej tezy warto przytoczyć wyrok NSA z dnia 1 marca 2005 r., dotyczący analogicznej sytuacji występującej w przypadku ustaw samorządowych. Zgodnie z tym wyrokiem z faktu przynależności do wspólnoty samorządowej nie można wyprowadzić interesu prawnego, którego naruszenie legitymowałoby do zaskarżania aktu organu jednostki samorządu terytorialnego ${ }^{75}$.

\subsection{Podstawa legitymacji skargi jednostki samorządu terytorialnego na rozstrzygnięcie organu nadzoru}

Regulacja art. 98 ust. 3 u.s.g., art. 85 ust. 3 u.s.p. i art. 86 ust. 2 u.s.w. legitymuje do składania skargi na rozstrzygnięcie nadzorcze wyłącznie gminę, związek między gminny, powiat i województwo (to JST będzie w tym przypadku stroną skarżącą). Powyższe regulacje mają charakter lex specialis

72 Choć ustawa ta wprowadza kilka istotnych zmian, m.in. zamknięty katalog funkcji wojewody czy też przeniesienie zadań administracji publicznej, które dotychczas wykonywane były przez wojewodę, do samorządu wojewódzkiego, to jednak pozostawia taką sama regulację w zakresie legitymacji skargowej. Brzmienie art. 63 i 64 ustawy o wojewodzie i administracji rządowej w województwie jest praktycznie tożsame z brzmieniem art. 44 i 45 poprzedniej ustawy z dnia 5 czerwca 1998 r. o administracji rządowej w województwie (tekst jedn.: Dz. U. z 2001 r. Nr 80, poz. 872). Biorąc ten fakt pod uwagę, racjonalnym posunięciem wydaje się być rozważenie tez postawionych w piśmiennictwie (K. Bandarzewski, M. Chlipała, P. Chmielnicki, P. Dąbek, W. Kisiel, M. Mączyński, S. Płażek, Komentarz do ustawy o administracji rządowej w województwie, Warszawa 2007) w zakresie, w jakim dotyczą one legitymacji skargowej.

73 Art. 63 ustawy o wojewodzie i administracji rządowej w województwie.

74 Zob. K. Bandarzewski, M. Chlipała, P. Chmielnicki, P. Dąbek, W. Kisiel, M. Mączyński, S. Płażek, Komentarz do ustawy o administracji rzadowej..., s. 330.

75 Wyrok NSA z dnia 1 marca 2005 r., OSK 1437/04, „Wokanda” 2005, nr 7-8, poz. 69. 
w stosunku do art. 50 p.s.a., wyłączają więc stosowanie go przy zaskarżaniu aktów nadzoru. Do aktów nadzoru zalicza się ${ }^{76}$ : orzeczenie stwierdzające nieważność uchwały organu JST, orzeczenie stwierdzające niezgodność z prawem uchwały organu JST, orzeczenie o podjęciu uchwały budżetowej $\mathrm{z}$ naruszeniem prawa, uchwałę kolegium regionalnej izby obrachunkowej $\mathrm{w}$ przedmiocie zastępczego ustalenia budżetu gminy $\mathrm{w}$ zakresie obowiązkowych zadań własnych i zleconych, wstrzymanie wykonania uchwały organu JST w przedmiocie wykonywania zadań zleconych, uchylenie uchwały organu JST w zakresie zadań zleconych i wydanie zamiast niej zarządzenia zastępczego, zarządzenie ministra zmieniające zarządzenie zastępcze wojewody, uchwałę Sejmu rozwiązującą radę gminy oraz zarządzenie Prezesa Rady Ministrów zawieszające organy gminy i ustanawiające komisarza rządowego. Podstawą legitymacji skargowej w stosunku do rozstrzygnięć nadzorczych jest naruszenie interesu prawnego, uprawnienia lub kompetencji jednostki samorządu terytorialnego (art. 98 ust. 3 u.s.g., art. 85 ust. 3 u.s.p. i art. 85 ust. 2 u.s.w.). Interes prawny nie jest tożsamy z interesem występującym w legitymacji do złożenia skargi na rozstrzygnięcie w sprawie indywidualnej z zakresu art. $50 \$ 1$ p.p.s.a. W przypadku ustaw samorządowych oraz ustawy o administracji rządowej chodzi o interes prawny, istniejący już w chwili wydania zaskarżanego aktu bądź w chwili wykonywania zaskarżanej czynności. Interes ten istnieje niezależnie od postępowania sądowoadministracyjnego i dopiero jego naruszenie aktem nadzoru umożliwia złożenie skargi ${ }^{77}$. Interes prawny dotyczy całej jednostki samorządy terytorialnego, a nie jej konkretnego organu. Jednak niezależnie od interesu prawnego $\mathrm{w}$ omawianej legitymacji skargowej występuje pewna niejasność: czy uprawniony do uchwalenia uchwały o zaskarżeniu aktu nadzoru jest jedynie organ, który wydał akt będący przedmiotem rozstrzygnięcia nadzorczego, czy też każdy organ danej JST? Można dopuścić możliwość zaskarżania przez wszystkie organy JST, ale z całą pewnością należy

76 Dla pełnej jasności zakresu tej legitymacji skargowej należy sprecyzować, jakie akty są uznawane za akty nadzoru - są to akty podejmowane przez organy nadzoru bieżącego i zwierzchniego, które odznaczają się cechami rozstrzygnięcia nadzorczego, inaczej władczego, aktu organu nadzoru.

77 Precyzując kwestie techniczne, trzeba stwierdzić, że podstawą do wniesienia przez uprawnione jednostki samorządu terytorialnego skargi na rozstrzygniecie nadzorcze jest uchwała organu, który podjął uchwałę zakwestionowaną przez organ nadzorczy. Tak oto na podstawie art. 86 ust. 3 u.s.w. do złożenia skargi na rozstrzygniecie nadzorcze dotyczące uchwały sejmiku województwa uprawniony jest właśnie ów sejmik. Co ciekawe, w sytuacji gdy rozstrzygnięcie nadzorcze zostało wydane po upływie kadencji sejmiku, który wydał uchwałę, na podstawie art. 86 ust. 2a u.s.w. sejmik następnej kadencji w terminie 30 dni od dnia wyboru przewodniczącego sejmiku jest uprawniony do składania skargi w sprawie uchwały poprzedniego składu (zob. B. Adamiak, J. Borkowski, Postępowanie administracyjne i sądowoadministracyjne, Warszawa 2009, s. 426). Rozwiązanie takie wydaje się wyraźnie obrazować, iż to nie organ jako taki jest skarżącym, a raczej cała jednostka. Sytuacja ta występuje także w przypadku powiatów i gmin odpowiednio w art. 85 ust. 3a u.s.p. oraz art. 98 ust. 3a u.s.g. 
odrzucić legitymację do wniesienia skargi przez zarząd na rozstrzygnięcie nadzorcze dotyczące uchwały rady. Taka kompetencja dawałaby zarządowi zwierzchnią rolę nad radą, umożliwiając decydowanie, jaka uchwała rady powinna podlegać ochronie sądowej. Podobne rozstrzygnięcie przyjął Sąd Najwyższy, orzekając w składzie siedmiu sędziów ${ }^{78}$. Kompetencji organu do wniesienia skargi nie należy mylić z upoważnieniem do wniesienia skargi np. upoważnienie przewodniczącego rady przez radę gminy. Wówczas przewodniczący będzie wnosił skargę z upoważnienia rady, a w imieniu całej jednostki ${ }^{79}$.

Zagadnieniem szczególnie interesującym jest problem legitymacji skargowej jednostek samorządu terytorialnego i ich organów w przypadku ich uprawnienia do orzekania w pierwszej instancji. Innymi słowy, chodzi o to, czy dana jednostka (przykładowo gmina) jest podmiotem uprawnionym do wniesienia skargi do sądu administracyjnego na decyzje administracyjną wydaną przez organ drugiej instancji, jeśli do wydania decyzji w pierwszej instancji upoważniony jest jej organ (odpowiednio do powołanego przykładu wójt gminy). Spory w tym przedmiocie były toczone od lat 90. NSA oraz Sąd Najwyższy przedstawiały zmienne i różniące się od siebie stanowiska. Ostatecznym rozwiązaniem kwestii legitymacji skargowej jednostek samorządu terytorialnego i ich organów w przypadku ich uprawnienia do orzekania w pierwszej instancji stał się wyrok Trybunału Konstytucyjnego z dnia 29 października 2009 r ${ }^{80}$ Rada Gminy i Miasta Koziegłowy wniosła wniosek o zbadanie zgodności z art. 165 ust. 1 i 2 Konstytucji „art. $33 \$ 1$ i 2 ustawy z dnia 30 sierpnia 2002 r. - Prawo o postępowaniu przed sądami administracyjnymi (...) w zakresie, $\mathrm{w}$ jakim pozbawia prawa do udziału na prawach strony $\mathrm{w}$ postępowaniu sądowoadministracyjnym gminę, której wójt (burmistrz, prezydent) wydał jako organ podatkowy pierwszej instancji decyzję podatkową, a podatek stanowi dochód tej gminy w sytuacji, gdy przedmiotem tego postępowania sądowoadministracyjnego jest decyzja organu odwoławczego w sprawie tego podatku". Drugą kwestią podniesioną we wniosku do Trybunału była zgodność „art. $50 \$ 1$ [p.p.s.a. - przyp. R.K.] $\mathrm{w}$ zakresie, $\mathrm{w}$ jakim pozbawia gminę prawa wniesienia skargi na decyzję organu wyższej instancji wydaną w wyniku rozpatrzenia odwołania od decyzji wydanej w pierwszej instancji przez wójta (burmistrza, prezydenta) tej gminy w sytuacji, gdy decyzja organu odwoławczego ma wpływ na prawa i obowiązki tej gminy lub jej organów, z art. 165 ust. 1 i 2 Konstytucji” ${ }^{81}$. Trybunał Konstytucyjny orzekł: „Art. 33 i art. $50 \$ 1$ ustawy z dnia 30 sierpnia 2002 r. - Prawo o postępowaniu przed sądami administracyjnymi (...)

78 Uchwała składu siedmiu sędziów Sądu Najwyższego z dnia 27 lutego 1992 r., III AZP 8/91, „Orzecznictwo Sądów Polskich” 1992, z. 10, poz. 222.

79 Zob. W. Chróścielewski, Sądowa kontrola..., s. 53.

80 K 32/08, Dz. U. Nr 187, poz. 1456.

81 Ibidem. 
są zgodne z art. 165 Konstytucji Rzeczypospolitej Polskiej"s2. Słuszna więc okazała się teza, że „gmina nie jest stroną postępowania administracyjnego $\mathrm{w}$ rozumieniu 28 k.p.a. i nie jest podmiotem uprawnionym do wniesienia skargi do sądu administracyjnego na decyzję administracyjną choćby nawet miała w tym interes prawny (...) jeśli do wydania decyzji w pierwszej instancji upoważniony jest wójt tej gminy"s3.

\section{Legitymacja skargowa w pozostałych ustawach stanowiących lex specialis w stosunku do Prawa o postępowaniu przed sądami administracyjnymi}

Jak już zostało wyłuszczone przy omówieniu skargi z zakresu ustaw samorządowych i ustawy administracji rządowej, art. $50 \$ 2$ p.p.s.a. ustanawia możliwość wprowadzenia legitymacji skargowej przez ustawy szczególne w stosunku do tej ustawy. To ogólne odesłanie do innych ustaw stanowi de facto określenie podmiotów legitymowanych do zaskarżania za pomocą klauzuli generalnej. Czynnikiem wyróżniającym omawiane regulacje jest fakt, że podmioty uprawnione do wnoszenia skarg na podstawie lex specialis mogą zaskarżać tylko określone działania w określonych rodzajach spraw ${ }^{84}$. Najczęściej ustawy szczególne nie będą kształtować nowych przesłanek legitymacji skargowej w stosunku podmiotów, które regulacje te wymieniają jako uprawnione do wnoszenia skargi. Co więcej, w większości przypadków ustawy takie ograniczają się jedynie do wyznaczenia podmiotów legitymowanych do wniesienia skargi. W takiej sytuacji wskazane jest odcięcie się od teorii o zróżnicowaniu na podstawie ustaw szczególnych przesłanek legitymacji skargowej, które miałoby wynikać ze zróżnicowania form aktywności organów administracji i innych podmiotów ${ }^{85}$. W tym miejscu należy dokonać selekcji lex specialis wprowadzających legitymację skargową w licznych zróżnicowanych przypadkach. Omówieniu będą podlegać jedynie wybrane przypadki, które rodzą wątpliwości natury prawnej.

82 Ibidem.

83 Zob. T. Woś, Glosa do uchwały składu siedmiu sędziów NSA z 19 maja 2003 r. (OPS 1/03), „Samorząd Terytorialny” 2004, nr 12, s. 79.

84 Zob. J. Tarno, Prawo o postępowaniu..., s. 160-161. Ponadto należy wskazać, iż delegacja zawarta $\mathrm{w}$ art. $50 \$ 2$ koresponduje $\mathrm{z}$ art. $3 \$ 3$ p.p.s.a., tzn. $\mathrm{z}$ zasadą, zgodnie $\mathrm{z}$ którą sądy mogą orzekać $\mathrm{w}$ sprawach, w których przepisy lex specialis przewidują kontrolę sądową w odniesieniu do określonych rodzajów działania organów administracji publicznej oraz, co ciekawe, także innych podmiotów legitymowanych na podstawie tych ustaw szczególnych.

85 Wyszczególnienie przez niektórych przedstawicieli doktryny różnych podstaw legitymacji, takich jak ochrona interesu społecznego (zob. w szczególności B. Adamiak, J. Borkowski, Postępowanie administracyjne..., 2009, s. 430), ma charakter czysto teoretycznego przyporządkowania legitymacji do różnych kategorii, mającego zapewnić łatwiejsze zrozumienie intencji ustawodawcy i nie powinno wpływać na różnicowanie legitymacji w sensie praktycznym, np. przy fakcie określania, czy legitymacja ta przysługuje danemu podmiotowi. 
Z uwagi na założenia niniejszego artykułu fakt, iż samorządy zawodowe ${ }^{86}$ nie są zaliczane do organów administracji publicznej sensu stricto, wyklucza omówienie legitymacji skargowej przy okazji ich działann ${ }^{87}$. Wskazane jest także wykluczenie $\mathrm{z}$ kręgu omawianych legitymacji skargowych legitymacji organów, w których zakresie obowiązków mieścić się będą sprawy etyki zawodowej ${ }^{88}$, ponieważ ich skargi również dotyczą działań podmiotów wychodzących poza ścisły obszar administracji publicznej. Legitymacją, która winna podlegać omówieniu, z uwagi na jej wpływ na działania administracji publicznej sensu stricto, jest legitymacja utworzona przez ustawę - Prawo własności przemysłowej ${ }^{89}$. Zasługuje ona na dodatkowe wyróżnienie z uwagi na fakt, iż obok nowej legitymacji skargowej wprowadza też zawężenie wobec legitymacji prokuratora i RPO. Na mocy omawianego lex specialis w stosunku do regulacji Prawa o postępowaniu przed sądami administracyjnymi powstaje możliwość zaskarżenia przez Prezesa Urzędu Patentowego prawomocnego orzeczenia Urzędu Patentowego rażąco naruszającego prawo $\mathrm{w}$ terminie sześciu miesięcy od dnia doręczenia stronie. Ponadto regulacja uprawnia do złożenia skargi przez prokuratora i RPO na tych samych zasadach ${ }^{90}$. Wyszczególnienie przymiotu naruszenia, jakim jest określenie „rażąco", powoduje zawężenie legitymacji skargowej Prezesa Urzędu Patentowego oraz prokuratora i RPO w sprawach dotyczących prawomocnych orzeczeń Urzędu Patentowego poprzez wymóg spełnienia dodatkowej przesłanki. Tym samym zarówno prokurator (którego podstawowym zadaniem jest ochrona porządku prawnego), jak i RPO nie będą mogli zaskarżyć każdego prawomocnego orzeczenia Urzędu Patentowego

86 Takie jak ustawa o samorządzie pielęgniarek i położnych, ustawa o zawodzie lekarza weterynarii i izbach lekarsko-weterynaryjnych czy też ustawa o izbach aptekarskich.

87 Co ciekawe, legitymowane na podstawie tych ustaw nie są podmioty będące organizacyjnie przynależne do regulowanych tą ustawą samorządów, a organy nadzoru nad nimi. Najczęściej będą to ministrowie poszczególnych resortów.

88 W zależności od funkcji takiego organu będzie się on zajmował etyką zawodową określonej, właściwej mu grupy zawodowej lub korporacji. Tak oto krajowi i okręgowi rzecznicy odpowiedzialności zawodowej będą legitymowani do zaskarżania w zakresie odpowiedzialności zawodowej członków izb architektów i inżynierów budownictwa na podstawie tej samej ustawy, która upoważniała ministrów: właściwego do spraw architektury i budownictwa oraz do spraw gospodarki przestrzennej i mieszkaniowej do zaskarżania uchwał Krajowych Izb: architektów, urbanistów oraz inżynierów budownictwa. Tak więc jedna ustawa specjalna nie tylko nadaje legitymację skargową różnym podmiotom, ale także legitymuje do zaskarżania różnych, dokładnie sprecyzowanych kategorii aktów w zależności od przywołanego podmiotu. Tworzy to więc stosunkowo złożoną sytuację, gdzie każda pojedyncza ustawa stanowiąca lex specialis może legitymować liczne podmioty, a każdy z nich będzie posiadał ową legitymacje do zaskarżania precyzyjnie określonych aktów.

89 Art. 254 ustawy z dnia 30 czerwca 2000 r. - Prawo własności przemysłowej, tekst jedn.: Dz. U. z 2017 r. poz. 776 ze zm.

90 W. Chróścielewski, Strony i uczestnicy..., s. 34. 
naruszającego obowiązujący porządek prawny. Dopiero przypadek rażącego naruszenia prawa będzie otwierał drogę do zaskarżania orzeczenia Urzędu Patentowego. Stanowi to wyjątkową, choć nie jedyną sytuację, gdy ustawa szczególna sama różnicuje przesłanki legitymacji skargowej w stosunku do regulacji Prawa o postępowaniu przed sądami administracyjnymi w tej materii ${ }^{11}$. Inicjator referendum jest kolejnym legitymowanym na podstawie ustawy szczególnej podmiotem, którego sytuacja prawna wymaga szerszego omówienia. Na podstawie art. 20 ustawy o referendum lokalnym ${ }^{92}$ inicjator jest podmiotem legitymowanym do zaskarżania uchwały organu stanowiącego jednostki samorządu terytorialnego odrzucającej wniosek mieszkańców $\mathrm{w}$ sprawie przeprowadzenia referendum ${ }^{93}$. Choć zgodnie $\mathrm{z}$ powołanym przepisem wniosek $\mathrm{w}$ sprawie przeprowadzenia referendum zgłaszają mieszkańcy, to uprawnionym do zaskarżania jest sam inicjator, a więc niekoniecznie grupa mieszkańców ${ }^{94}$. Dla wyjaśnienia powyższej tezy należy przybliżyć ogólną charakterystykę i genezę instytucji referendum lokalnego. Ta forma udziału społeczeństwa w procesie decyzyjnym pochodzi z podstawowego aktu naszego systemu prawnego, czyli z Konstytucji. Zgodnie z art. 170 Konstytucji członkowie wspólnoty samorządowej mogą decydować o sprawach ich wspólnoty w drodze referendum. Rozwijając te zawarte Konstytucji wytyczne, art. 4 ustawy o referendum lokalnym stanowi, iż wniosek 10\% mieszkańców gminy bądź powiatu lub 5\% mieszkańców województwa uprawnionych do głosowania może prowadzić do przeprowadzenia referendum lokalnego na terenie jednostki samorządu terytorialnego, której mieszkańcy wnieśli wniosek. Oznacza to, że termin „inicjator” odnosi się tu do grupy mieszkańców ${ }^{95}$. Jednak prócz mieszkańców, na podstawie art. 11 ust. 1 pkt 2 i 3 ustawy o referendum lokalnym inicjatorem może być także statutowa struktura partii politycznej, która działa w danej JST oraz organizacja społeczna, posiadająca osobowość prawną, której statutowym terenem działania jest obszar przynajmniej jednej jednostki samorządu terytorialnego. Choć w ogólnym założeniu legitymacja

91 Zob. T. Woś, H. Knysiak-Molczyk, M. Romańska, Prawo o postępowaniu..., s. 289.

92 Ustawa z dnia 15 września 2000 r. o referendum lokalnym, tekst jedn.: Dz. U. z 2016 r. poz. 400 ze zm.

93 Po złożeniu wniosku do organu stanowiącego JST w terminie 30 dni powinna zostać wydana uchwała pozytywnie lub negatywnie rozstrzygająca wniosek o referendum.

94 Jak jednak zwraca się uwagę w doktrynie, mieszkańcy są wymienieni jako pierwszy, a w konsekwencji najważniejszy podmiot uprawniony do inicjowania referendum. Będą więc oni w intencji ustawodawcy głównym podmiotem legitymowanym do zaskarżenia (zob. P. Uziębło, Ustawa o referendum lokalnym: komentarz, Warszawa 2008, s. 60).

95 Zgodnie z art. 11 ustawy o referendum lokalnym liczba mieszkańców musi wynieść co najmniej 15, ponadto muszą oni posiadać pełnię praw wyborczych do wyboru organu stanowiącego danej jednostki samorządu terytorialnego. 
przysługuje inicjatorowi referendum wyłącznie na podstawie ustawy szczególnej, to pewne wątpliwości rodzi regulacja art. 11 ust. 1 pkt 3 ustawy o referendum lokalnym, zgodnie z którą skarżącym może być także organizacja społeczna. Pojawia się zatem niejasność, na podstawie której legitymacji organizacja społeczna będzie wnosić skargę. Z jednej strony mamy bowiem legitymację wynikającą z przepisów ustawy o referendum lokalnym, a $\mathrm{z}$ drugiej legitymację na podstawie art. $50 \$ 1$ p.p.s.a. Organizacja, będąc inicjatorem referendum, występuje w sprawie dotyczącej interesu prawnego innych osób, którymi w tym przypadku będą mieszkańcy danej jednostki. W takim wypadku zostanie spełniona przesłanka wprowadzona przez art. $50 \$ 1$ p.p.s.a., tworząca legitymację skargową organizacji społecznej, tj. konieczność zaskarżania celem ochrony interesu społecznego. Problematyczna jednak będzie druga przesłanka z art. $50 \$ 1$ p.p.s.a., a mianowicie wymóg brania udziału przez organizacje społeczną w postępowaniu administracyjnym. Procedury próby zainicjowania referendum nie można z powodzeniem zakwalifikować jako postępowania administracyjnego. $\mathrm{W}$ konsekwencji zgodne $\mathrm{z}$ intencją ustawodawcy wydaje się opowiedzenie się za przyznaniem legitymacji skargowej w omawianej sytuacji wyłącznie na bazie art. 11 ustawy o referendum lokalnym. Będzie to, jak w każdym przypadku legitymacji wywodzonej z lex specialis, uprawnienie szczególne podmiotu wskazanego przez ustawę szczególną jako skarżący. W takim ujęciu przesłanki, jakie organizacja społeczna musi spełnić dla uzyskania legitymacji $z$ art. $50 \$ 1$ p.p.s.a., nie obejmują legitymacji na podstawie art. 11 ustawy o referendum lokalnym. Podobnie będzie w przypadku innych inicjatorów $^{96}$. Konsekwencje powyższej tezy można przenieść w obszar pozostałych inicjatorów referendum ${ }^{97}$. Tak oto w przypadku grupy mieszkańców (dzięki przyjęciu koncepcji uprawnienia szczególnego wynikającego $\mathrm{z}$ art. 11 ustawy o referendum lokalnym) nie wystąpi omawiany wcześniej problem braku możliwości powołania się na zbiorowy interes prawny, ponieważ grupa ta nie będzie musiała się nim legitymować - będzie bowiem skarżyć na podstawie ustawy o referendum lokalnym.

\section{Podsumowanie}

W konkluzji należy stwierdzić, iż liczne uregulowania wycinka postępowania sądowoadministracyjnego, jakim jest legitymacja skargowa, tworzą złożoną, często nazbyt rozproszoną całość, która pełna jest wzajemnych zależności oraz niejednoznacznych przepisów wymagających specjalistycznej wykładni. Choć skalę wpływu tej tematyki na proces decyzyjny organów administracji należałoby poddać pogłębionej analizie od strony

96 Takie stanowisko zostało zaaprobowane w doktrynie, zob. A. Duda, Interes prawny..., s. 233-235.

97 Taką możliwość dostrzega A. Duda. 
socjologicznej, to już w oparciu o przedstawione rozważania prawne można obiektywnie stwierdzić, iż niepewność co do faktu, jaki podmiot i na jakich warunkach może zaskarżyć dane działanie organu administracyjnego, w znaczący sposób wpływa negatywnie na efektywność podejmowania decyzji w administracji publicznej. Pracownicy organów administracji nie pozostają bowiem obojętni na stosowane wobec nich metody oceny. System oceniania pracowników administracji publicznej najczęściej bazuje na zastosowaniu w dany sposób dwóch zmiennych ${ }^{98}$ : szybkości obsługi administracyjnej (innymi słowy, liczby załatwionych spraw administracyjnych) oraz ilości wydanych aktów administracyjnych uchylonych następne przez organ wyższego stopnia bądź sąd administracyjny. W interesie każdego pracownika pozostaje dążenie do jak najlepszej oceny jego pracy. W tym celu będzie się on skłaniał do optymalizacji nakładu pracy poprzez identyfikację spraw, w których wystąpi wiele podmiotów uprawnionych do zaskarżania (także w postępowaniu sądowoadministracyjnym), i w konsekwencji położy na nie większy nacisk. Takie działania będą wiązać się z podniesieniem efektywności procesów decyzyjnych w administracji poprzez zwiększenie ilości spraw administracyjnych, które nie zostaną następnie wzruszone w drodze kontroli sądowej. Sprawy, w których wystąpi wiele podmiotów uprawnionych do zaskarżania, będą najczęściej kategorią postępowań, w których może dojść do naruszenia interesu prawnego strony postępowania. W konsekwencji efektem działań pracownika administracji ukierunkowanych na ochronę jego własnych interesów (zapewnienie sobie jak najlepszej oceny wyników pracy) będą szczególne starania o prawidłowość rozstrzygnięć wpływających na interes prawny wielu podmiotów, co będzie pozostawać w zgodności z podstawowymi założeniami prawidłowego administrowania, takimi jak zasada pogłębienia zaufania obywateli do organów państwa sformułowana w art. 8 k.p.a. W takim ujęciu przeglądowe opracowanie problemu legitymacji skargowej stanowi systematyzację wiedzy z tego zakresu, niezbędną dla wsparcia procesu podejmowania decyzji poprzez zwiększenie świadomości prawnej wśród pracowników administracji publicznej.

98 Należy jednak zwrócić uwagę, iż ustawodawca nierzadko pozostawia dużą swobodę oceny pracowników administracji. Przykładowo zasady oceniania pracowników samorządowych zostały sprecyzowane w art. 27 i 28 ustawy z dnia 21 listopada 2008 r. o pracownikach samorządowych (Dz. U. z 2016 r. poz. 902 ze zm.). Obecnie kompetencje do określenia sposobu dokonywania ocen okresowych, okresów, za które sporządzana jest ocena, kryteriów, na podstawie których ocena jest dokonywana, oraz skali ocen posiada kierownik jednostki samorządowej (zob. A. Rycak, M. Rycak, J. Stelina, J. Stępień, Ustawa o pracownikach samorządowych. Komentarz, Warszawa 2016). Oznacza to większe zróżnicowanie zasad wystawiania ocen pracowników w poszczególnych jednostkach administracji samorządowej (zob. I. Seredocha, Pracownicy samorządowi: nowe - stare zasady oceniania pracowników samorządowych, „Serwis Samorządowy”, LEX 2010). 


\section{Bibliografia}

Adamiak B., Borkowski J., Postępowanie administracyjne i sądowoadministracyjne, Warszawa 2005.

Adamiak B., Borkowski J., Postępowanie administracyjne i sq̨dowoadministracyjne, Warszawa 2009.

Bandarzewski K., Chlipała M., Chmielnicki P., Dąbek P., Kisiel W., Mączyński M., Płażek S., Komentarz do ustawy o administracji rzadowej w województwie, Warszawa 2007.

Borkowski J., Glosa do wyroku NSA z 27 września 2000 r., II SA 2109/2000, „Orzecznictwo Sądów Polskich" 2001, z. 6.

Brzozowski P., Glosa do uchwały NSA z dnia 10 kwietnia 2006 r., I OPS 6/05, LEX nr 385958940.

Chmielnicki P., Bandarzewski K., Dobosz P., Kisiel W., Kryczko P., Mączyński M., Płażek S., Komentarz do ustawy o samorzadzie gminnym, Warszawa 2007.

Chorąży K., Taras W., Wróbel A., Postępowanie administracyjne egzekucyjne i sądowoadministracyjne, Kraków 2009.

Chróścielewski W., Wszczęcie postępowania sądowoadministracyjnego, „Państwo i Prawo" 2004, z. 3.

Chróścielewski W., Glosa do wyroku WSA w Warszawie z dnia 27 stycznia 2004 r., III SA 1617/02, „Orzecznictwo Sądów Polskich” 2005, z. 11, poz. 128.

Chróścielewski W., Legitymacja skargowa $w$ postępowaniu sąowoadministracyjnym, „Zeszyty Naukowe Sądownictwa Administracyjnego” 2010, nr 5-6.

Dauter B., Gruszczyński B., Kabat A., Niezgódka-Medek M., Prawo o postępowaniu przed sądami administracyjnymi. Komentarz, Warszawa 2009.

Duda A., Interes prawny w polskim prawie administracyjnym, Warszawa 2008.

Knysiak-Sudyka H., Skarga i skarga kasacyjna w postępowaniu sądowoadministracyjnym. Komentarz i orzecznictwo, Warszawa 2016.

Lemańska J., Koncepcja samorządu województwa na tle porównawczym, Kraków 2006.

Lewandowski T., Glosa do wyroku WSA z dnia 2 kwietnia 2012 r., I SAB/Wa 67/12, LEX nr 386030691.

Mrówczyński M., Legitymacja skargowa w postępowaniu sądowoadministracyjnym wynikająca z ustaw szczególnych, „Zeszyty Naukowe Sądownictwa Administracyjnego" 2015, nr 6.

Rycak A., Rycak M., Stelina J., Stępień J., Ustawa o pracownikach samorządowych. Komentarz, Warszawa 2016.

Seredocha I., Pracownicy samorządowi: nowe - stare zasady oceniania pracowników samorządowych, „Serwis Samorządowy”, LEX 2010.

Tarno J., Prawo o postępowaniu przed sądami administracyjnymi. Komentarz, Warszawa 2009.

Uziębło P., Ustawa o referendum lokalnym: komentarz, Warszawa 2008.

Trociuk S., Ustawa o Rzeczniku Praw Obywatelskich. Komentarz, Łódź 2005.

Woś T., Glosa do wyroku z 26 VI 1992, III ARN 31/92, „Państwo i Prawo” 1995, z. 2. 
Woś T., Glosa do uchwały składu siedmiu sędziów NSA z 19 maja 2003 r. (OPS 1/03), „Samorząd Terytorialny” 2004, nr 12.

Woś T. [w:] Postępowanie sądowoadministracyjne, T. Woś (red.), Warszawa 2015.

Woś T., Knysiak-Molczyk H., Romańska M., Prawo o postępowaniu przed sądami administracyjnymi. Komentarz, T. Woś (red.), Kraków 2009.

Woś T., Knysiak-Sudyka H., Romańska M., Prawo o postępowaniu przed sądami administracyjnymi. Komentarz, T. Woś (red.), Warszawa 2016.

Zimmermann J., Polskie sadownictwo administracyjne (uwagi o projekcie ustawy o Naczelnym Sądzie Administracyjnym), „Krakowskie Studia Prawnicze” 19931994.

Zimmermann J., Glosa do wyroku NSA $z$ dnia 2 lutego 1996 r., sygn. akt IV SA 846/95, „Orzecznictwo Sądów Polskich” 1997, z. 4, poz. 83.

Zimmermann J., Konstrukcja interesu prawnego w sferze działań Naczelnego Sądu Administracyjnego [w:] Gospodarka, administracja, samorząd. Księga dedykowana Profesor Teresie Rabskiej, „Prace Wydziału Prawa i Administracji Uniwersytetu im. Adama Mickiewicza w Poznaniu”, t. II, H. Olszewski, B. Popowska (red.), Poznań 1997.

Zimmermann J., Glosa do postanowienia NSA z dnia 19 sierpnia 2004 r., OZ 340/04, „Orzecznictwo Sądów Polskich” 2005, z. 4.

Zimmermann J., Prawo administracyjne, Warszawa 2008.

Streszczenie

Ogólna ocena systemu norm prawnych dotyczących legitymacji skargowej w postępowaniu sądowoadministracyjnym prowadzi do konkluzji, iż z uwagi na liczbę aktów prawnych oraz poziom ich złożoności wystąpią istotne ograniczenia w procesach decyzyjnych organów administracji publicznej. Uzyskanie przez pracowników organów administracji optymalnej wiedzy, jaki podmiot, w jakim czasie i na jakich warunkach może zaskarżyć ich dane, wpływa znacznie na efektywność podejmowania decyzji. Prezentowany artykuł przedstawia przeglądowe opracowanie poglądów doktrynalnych oraz analizę utrwalonych linii orzecznictwa z zakresu tej tematyki.

Opracowanie składa się z czterech segmentów, w których omówiono kolejno: instytucję legitymacji skargowej o tzw. charakterze uniwersalnym, z zaznaczeniem wykluczeń podmiotowych i analizą znaczenia interesu prawnego, w kontekście identyfikacji podmiotów uprawnionych do zaskarżania; legitymację podmiotów składających skargę w cudzej sprawie, takich jak prokurator, Rzecznik Praw Obywatelskich, Rzecznik Praw Dziecka oraz organizacja społeczna; legitymację do wniesienia skargi na mocy ustaw samorządowych oraz ustawy o wojewodzie i administracji rządowej w województwie, ze szczególnym naciskiem na podstawę legitymacji skargowej JST na rozstrzygnięcie organu nadzoru oraz ograniczeń w zaskarżaniu uchwały, czynności lub braku czynności organu JST; szczególne uprawnienia do zaskarżenia działań administracji, wynikających z ustaw stanowiących lex specialis w stosunku do Prawa o postępowaniu przed sądami administracyjnymi.

Słowa kluczowe: postępowanie administracyjne, legitymacja skargowa, efektywność podejmowania decyzji w administracji publicznej 


\section{The Complaint-Filing Right in Administrative Court Proceedings as an Aspect Influencing Decision-Making Efficiency in Public Administration}

Abstract

An overall assessment of the current system of the authorisation to file a complaint have led to the conclusion that a sheer number of regulations and the level of their complexity prevent it from being transparent enough to support efficiency in public administration. An optimal level of knowledge as regards who, when and on what conditions can file a complaint will be helpful in the decision-making applied by public administration officials. Therefore, this article aims to provide the readers with a summary of doctrine views and court judgements as well as analysis of the complaint-filing right. It is hoped that this contribution considerably helps improve decision-making efficiency in public administration.

The first chapter of the article focuses on one of most popular authorisations to file a complaint, often described as a universal complaint-filing right. The second chapter includes analysis of the authorisation to file a complaint in someone else's case. Subsections describe complaint-filing authorisation for prosecutors, the Ombudsman, the Children's Ombudsman and social organisations. The third chapter provides a description of the authorisation to file a complaint introduced by local-government acts. Its individual subsections examine the authorisation to file a complaint under local-government resolutions and under the act on the supervision of local-government units. The last chapter reviews the complaint-filing right in other lex specialis acts in relation to the Administrative Court Proceedings Act.

Keywords: administrative proceedings, complaint-filing right, decision-making efficiency in public administration 